\title{
EFFECT OF NANOFLUID ON HEAT TRANSFER CHARACTERISTICS OF DOUBLE PIPE HEAT EXCHANGER: PART-II: EFFECT OF COPPER OXIDE NANOFLUID
}

\author{
N. K. Chavda ${ }^{1}$ \\ ${ }^{1}$ Associate Professor, Department of Mechanical Engineering, A. D. Patel Institute of Technology, New Vallabh \\ Vidyanagar - 388121
}

\begin{abstract}
A nanofluid is a suspension of nano sized particles made up of metal, oxides or carbides of size up to $100 \mathrm{~nm}$ in a base fluid of water, ethylene glycol or oil. Recently large numbers of experiments have been are carried out to evaluate the effect of nanofluid in enhancement of the heat transfer rate in various heat exchangers. The heat transfer enhancement using nanofluid mainly depends on type of nanoparticles, size of nanoparticles, shape of nanoparticles, type of base fluid and concentration of nanoparticles in the base fluid. In the present paper, an experimental evaluation has been carried out to determine the effect of various concentration of $\mathrm{CuO}$ nanoparticles mixed in water on heat transfer characteristics of double pipe heat exchanger for parallel flow and counter flow arrangement. The volume concentrations of $\mathrm{CuO}$ nanofluid prepared by two step method are 0.002 $\%, 0.003 \%$ and $0.004 \%$. The conclusion derived for the study is that overall heat transfer coefficient increases with increase in volume concentration of $\mathrm{CuO}$ nanoparticle compared to water which have been validated by theoretical prediction also.
\end{abstract}

Keywords: Nanofluid, Heat Transfer Characteristics, Double Pipe Heat Exchanger, CuO Nanoparticles

\section{INTRODUCTION}

Various types of industries employ different types of heat exchangers to exchange the heat between cold and hold stream and inspect/modify them time to time to optimize the heat transfer rate. The augmentation in heat transfer rate is possible to achieve by two steps viz. (1) By optimizing the design of the heat exchanger and (2) By optimizing the operational parameters. Optimization of the operational parameters plays a key role in enhancement of heat transfer rate after the heat exchanger is designed.

Active methods and passive methods are the possible ways to enhance the heat transfer rate operationally. Active method includes electro hydrodynamics, jets, sprays, ultrasound waves, synthetic jet heat transfer and high amplitude vibratory motion, while passive method include surface coating, nanoscale coating, nanofluid, hydrodynamic cavitations, turbulence promoters and mixing promoters [1]. Among them, three methods are considered as effective methods to enhance the heat transfer which are (1) Using Nanofluids, (2) Inserting Fluid Tabulators and (3) Roughing the Heat Exchanger Surface.

A nanofluid is a suspension of nano sized particles made up of metal, oxides or carbides of size up to $100 \mathrm{~nm}$ in a base fluid of water, ethylene glycol or oil. The nanofluids exhibit different thermo physical properties than the base fluid. As the thermal conductivity of nanofluids is higher than the base fluid, the heat transfer rate of nanofluid is also higher. The heat transfer enhancement using nanofluid mainly depends on type of nanoparticles, size of nanoparticles, shape of nanoparticles, type of base fluid and concentration of nanoparticles in base fluid. In the first part of the paper [2], effect of $\mathrm{Al}_{2} \mathrm{O}_{3}$ nanofluid on heat transfer characteristics of double pipe heat exchanger has been experimentally evaluated and in the similar way, the effect of $\mathrm{CuO}$ nanofluid has been evaluated experimentally and validated theoretically in this paper.

A comprehensive review of published papers in last ten years and available in open literature related to the application of $\mathrm{CuO}$ nanofluid in heat transfer has been carried out. The chronological detailed review of seventeen published papers [3-19] pertaining to application of $\mathrm{CuO}$ nanofluid in heat exchanger is presented below.

Abed, A. M. et. al.[3] in 2015 have numerically studied the effect of fully developed turbulent flow and heat transfer behavior in trapezoidal channels using nanofluids having four different types of nanoparticles, $\mathrm{Al}_{2} \mathrm{O}_{3}, \mathrm{CuO}, \mathrm{SiO}_{2}$ and $\mathrm{ZnO}$, with different volume fractions $(0-4 \%)$ and diameters $(20-80 \mathrm{~nm})$ under constant heat flux $\left(6 \mathrm{~kW} / \mathrm{m}^{2}\right)$. They have found that $\mathrm{SiO}_{2}$ nanofluid has the highest Nusselt number among the nanofluids. Based on the analysis of the flow and heat transfer in a corrugated trapezoidal channel using comprehensive evaluation factor $\mathrm{J} / \mathrm{f}$, the optimum (J/f) enhancement have been found in the case of $\mathrm{CuO}$ nanofluid for saving energy. Nikkhah, V. et. al. [4] in 2015 have studied the effect of heat and mass flux, concentration of nanofluids on scale formation in term of fouling resistance in convective and nucleate boiling heat transfer domains at different operating conditions. They have proposed a new correlation based on the experimental data 
at isothermal/diffusion flow conditions which can predict the fouling resistance of $\mathrm{CuO} /$ water nanofluids with Absolute Average Deviation of (less than) 30\% which implies on a fair agreement to experimental data. Peyghambarzadeh, S. M. et. al. [5] in 2014 have investigated single phase forced convective heat transfer and fluid flow of $\mathrm{CuO}$ /water and $\mathrm{Al}_{2} \mathrm{O}_{3}$ /water nanofluids in a microchannel heat sink (MCHS) consisted of 17 rectangular cross section microchannels with the dimensions of $400 \mu \mathrm{m} \times 560 \mu \mathrm{m}$ at constant heat flux of $19 \mathrm{~W} / \mathrm{cm}^{2}$ and at the laminar flow regime $500<\operatorname{Re}<2000$ and measured heat transfer coefficient, $\mathrm{Nu}$ number, and also pressure drop in the same and compared with the conventional correlations. They found that at $0.2 \mathrm{vol} \% \mathrm{CuO}$ and $1 \mathrm{vol} \% \quad \mathrm{Al}_{2} \mathrm{O}_{3}$ nanofluids enhance the heat transfer coefficient up to $27 \%$ and $49 \%$, respectively and concluded that $\mathrm{CuO}$ nanoparticle was more efficient.

Ndoye, F. T. et. al. [6] in 2014 have developed a mathematical model in order to predict the energy performances of refrigerating systems using nanofluids having various types of nanoparticles $\left(\mathrm{Al}_{2} \mathrm{O}_{3}, \mathrm{Co}, \mathrm{CuO}, \mathrm{Fe}\right.$, $\mathrm{SiO}_{2}$ and $\mathrm{TiO}_{2}$ ) and a wide range of volume fraction. They have found that the energy performance is strongly dependent on the type of nanoparticles: some of the studied nanofluids $\left(\mathrm{Al}_{2} \mathrm{O} 3, \mathrm{SiO}_{2}\right.$ and $\left.\mathrm{TiO}_{2}\right)$ were clearly less efficient than the base fluid while the others $(\mathrm{Co}, \mathrm{CuO}, \mathrm{Fe})$ had a favorable energy performance with PEC values reaching 80\%. Khairul, M. A. et. al. [7] in 2014 have presented the fuzzy logic expert system (FLES) for heat transfer performance investigation in helically coiled heat exchanger with spirally corrugated wall operated with water and $\mathrm{CuO} /$ water nanofluids to investigate the relationship between heat exchanger working parameters and performance characteristics, and to determine how fuzzy logic expert system plays a significant role in prediction of heat transfer performance. They have found that the heat transfer coefficients of $\mathrm{CuO} /$ water nanofluids significantly increased about $5.90-14.24 \%$ with the increase of volume concentrations compared to water. Khairul, M. A. et. al. [8] in 2014 have examined the effects of water and $\mathrm{CuO} /$ water nanofluids (as coolants) on heat transfer coefficient, heat transfer rate, frictional loss, pressure drop, pumping power and exergy destruction in the corrugated plate heat exchanger and found that the heat transfer coefficient of $\mathrm{CuO} /$ water nanofluids increases about 18.50 to $27.20 \%$ with the enhancement of nanoparticles volume concentration from 0.50 to $1.50 \%$ compared to water. They have also reported that the exergy loss was reduced by $24 \%$ employing nanofluids as a heat transfer medium with compared to conventional fluid with a small penalty in the pumping power.

Khairul, K. A. et. al. [9] in 2013 have presented heat transfer and thermodynamic second law analysis of a helical coil heat exchanger using three different types of nanofluids (e.g. $\mathrm{CuO} /$ water, $\mathrm{Al}_{2} \mathrm{O}_{3} /$ water and $\mathrm{ZnO} /$ water) having volume fractions and volume flow rates in the range of $1-4 \%$ and $3-$ $6 \mathrm{~L} / \mathrm{min}$, respectively. They have reported that amongst the three nanofluids, for $\mathrm{CuO} /$ water nanofluid heat transfer enhancement and reduction of entropy generation rate were obtained about $7.14 \%$ and $6.14 \%$ respectively. Narrein K. and Mohammed H. A. [10] in 2013 have numerically investigated the effects of using various types of nanofluids and rotation on heat transfer and fluid flow characteristics in a helically coiled tube heat exchanger (HCTHE). They have analyzed the effects of nanoparticles type $\left(\mathrm{Al}_{2} \mathrm{O}_{3}, \mathrm{SiO}_{2}\right.$, $\mathrm{CuO}, \mathrm{ZnO})$, its concentration $(1-4 \%)$, and particle diameter $(25-80 \mathrm{~nm})$, base fluid type (water, ethylene glycol, engine oil), towards the heat transfer and fluid flow characteristics using three-dimensional steady, laminar flow and conjugate heat transfer governing equations of a balanced HCTHE and solved them using the finite volume method. They reported that Nusselt number is highest using $\mathrm{CuO}$-water nanofluid and rotation can be used to enhance the heat transfer rates. Mohammed, H. A. et. al. [11] in 2013 have numerically studied the effect of using louvered strip inserts placed in a circular double pipe heat exchanger having top and the bottom walls of the pipe heated with a uniform heat flux boundary condition and two different louvered strip insert arrangements (forward and backward) on the thermal and flow fields utilizing four types of nanofluids having $\mathrm{Al}_{2} \mathrm{O}_{3}$, $\mathrm{CuO}, \mathrm{SiO}_{2}$, and $\mathrm{ZnO}$ nanoparticles with different volume fractions in the range of $1 \%$ to $4 \%$ and different nanoparticle diameters in the range of $20 \mathrm{~nm}$ to $50 \mathrm{~nm}$, dispersed in a base fluid (water). They have found that $\mathrm{SiO}_{2}$ nanofluid has the highest Nusselt number value, followed by $\mathrm{Al}_{2} \mathrm{O} 3, \mathrm{ZnO}$, and $\mathrm{CuO}$ while pure water has the lowest Nusselt number.

Mohammed, H. A. and Narrein, K. [12] in 2012 have numerically studied the effects of using different geometrical parameters with the combination of $\mathrm{CuO}$ nanoparticle with a diameter of $25 \mathrm{~nm}$ dispersed in water and with a particle concentration of $4 \%$ on heat transfer and fluid flow characteristics in a helically coiled tube heat exchanger (HCTHE) for parallel and counter flow configuration. They found that certain geometrical parameters such as the helix radius and inner tube diameter affect the performance of the HCTHE under laminar flow conditions. Kannadasan, N. et. al. [13] in 2012 have experimentally studied the effect of $\mathrm{CuO} /$ water nanofluids having $0.1 \%$ and $0.2 \%$ volume concentrations on heat transfer and pressure drop characteristics of helically coiled heat exchanger held in horizontal and vertical positions. They have reported that irrespective of the positions of the helically coiled heat exchanger, the enhancement in internal Nusselt numbers is high for higher concentration nanofluids at turbulent flow. Kazemi-Beydokhti, A. and Heris, S. Z. [14] in 2012 have focused on an incomplete combined heat and power (CHP) system by designing a shell and tube heat exchanger to recover the heat from the exhaust gases to increase the efficiency of the heating system and a plate heat exchanger for cooling the biogas-diesel generator and the exhaust gases using two types of nanofluids with the same concentration $(4 \% \mathrm{v} / \mathrm{v})$ as the circulating fluid to recover heating power from the CHP system. They have found that nanofluids enhance the thermal performance of the CHP system, and the use of aqueous $\mathrm{CuO}$ is more advantageous than the use of aqueous $\mathrm{Al}_{2} \mathrm{O}_{3}$ as a cooling nanofluid. 
Huminic, G. and Huminic, A. [15] in 2011 have studied the effect of a three-dimensional analysis on the heat transfer characteristics of a double-tube helical heat exchangers using nanofluids having $\mathrm{CuO}$ and $\mathrm{TiO}_{2}$ nanoparticles with diameters of $24 \mathrm{~nm}$ dispersed in water with volume concentrations of $0.5-3 \mathrm{vol} . \%$ under laminar flow conditions. They have showed that for $2 \% \mathrm{CuO}$ nanoparticles in water and at a same mass flow rate in inner tube and annulus, the heat transfer rate of the nanofluid was approximately $14 \%$ greater than that of pure water and the heat transfer rate of water from annulus than through the inner tube flowing nanofluids was approximately $19 \%$ greater than for the case which through the inner and outer tubes flow water. Mohammed, H. A. et. al. [16] in 2011 have numerically analyzed the performance of a counterflow rectangular shaped micro channel heat exchanger (MCHE) using different nanofluids like $\mathrm{Ag}, \mathrm{Al}_{2} \mathrm{O}_{3}, \mathrm{CuO}$, $\mathrm{SiO}_{2}$, and $\mathrm{TiO}_{2}$ as the working fluids and results were compared with water. They reported that enhanced performance with the usage of nanofluids is possible with slight penalty in pressure drop. Zamzamian, A. et. al. [17] in 2011 have experimentally studied the effects of nanofluids of aluminum oxide and copper oxide prepared in ethylene glycol separately on forced convective heat transfer coefficient in turbulent flow in a double pipe and plate heat exchangers. Their findings include that there is a considerable enhancement in convective heat transfer coefficient of the nanofluids as compared to the base fluid, ranging from $2 \%$ to $50 \%$ and with increasing nanoparticles concentration and nanofluid temperature, the convective heat transfer coefficient of nanofluid increases. Pantzali, M. N. et. al. [18] in 2009 have studied experimentally and numerically the effect of the use of a nanofluid $(\mathrm{CuO}$ in Water, $4 \% \mathrm{v} / \mathrm{v}$ ) in a miniature plate heat exchanger (PHE) with modulated surface. The found that, for a given heat duty, the nanofluid volumetric flow rate required is lower than that of water causing lower pressure drop. The only drawbacks so far are the high price and the possible instability of the nanoparticle suspensions. Pantzali, M. N. et. al. [19] in 2009 experimentally investigated the efficacy of nanofluids namely a $4 \% \mathrm{CuO}$ suspension in water as coolants in a commercial herringbone-type plate heat exchangers. They found that besides the physical properties, the type of flow inside the heat exchanging equipment also affects the efficacy of a nanofluid as coolant.

The literature review concludes that the application of nanofluid in heat exchanger to augment the heat transfer rate is the relatively recent practice and the application of $\mathrm{CuO}$ nanofluid to enhance the heat transfer rate of double pipe heat exchanger rate is yet to be increased.

Extensive experiments have been carried out on double pipe heat exchanger to determine the effect of different type of nanofluids (having nanoparticles of $\mathrm{Al}_{2} \mathrm{O}_{3}$ and $\mathrm{CuO}$.) and concentration of nanoparticles in nanofluid during parallel and counter flow condition. In the part I of the paper, effect of $\mathrm{Al}_{2} \mathrm{O}_{3}$ nanofluid had been presented and in this part II of the paper effect of $\mathrm{CuO}$ nanofluid has been discussed.

\section{EXPERIMENTAL SETUP AND PROCEDURE}

Apparatus for double pipe heat exchanger is shown in Figure 1. The outer pipe is made up of SS 304 material having outer diameter, inner diameter and length of $36 \mathrm{~mm}$, $32 \mathrm{~mm}$ and $3 \mathrm{~m}$ respectively. The inner pipe is also made up of SS 304 having outer diameter, inner diameter and length of $18 \mathrm{~mm}, 15 \mathrm{~mm}$ and $3 \mathrm{~m}$ respectively. Cladding of mineral wool having $25 \mathrm{~mm}$ thickness is carried out which acts as insulation over outer pipe. Two valves are provided on each pipe which can be open and closed alternatively for counter and parallel flow operation. Two water tanks viz. (1) Cold Water and (2) Hot Water are provided with separate SS 304 mono-block type centrifugal pump to circulate cold and hot water through pipes respectively. Three immersion type heaters, each of $6 \mathrm{~kW}$ capacity are located in hot water tank to heat the water. Two Fitzer make rotameters, each of $0.5-$ $5.0 \mathrm{lpm}$ range are connected to measure the flow rate of cold water and hot water from the pipes. $J$ type thermocouples are used to measure the inlet and outlet temperatures of cold and hot water flowing through the pipes. Digital temperature indicator is provided to indicate the temperature.

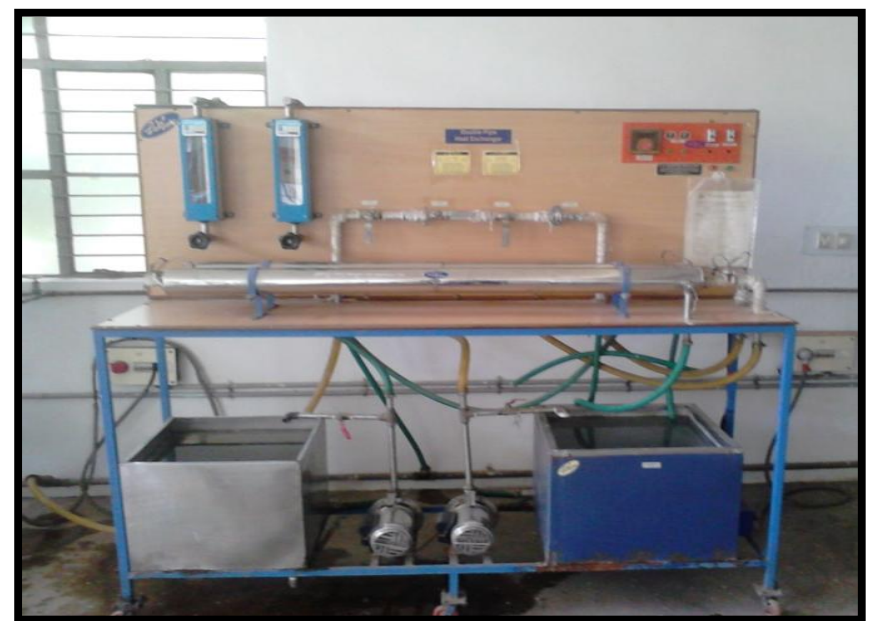

Fig. 1: Experimental Setup: Double Pipe Heat Exchanger Apparatus

\subsection{Experimental Procedure for Double Pipe Heat}

\section{Exchanger}

(1) Fill water in cold and hot water tank.

(2) Switch on the immersion type heater provided in the hot water tank and heat the water to the desired temperature.

(3) Switch "ON" the pump provided in hot water tank with bypass line valve fully open and supply valve fully closed to ensure thorough mixing of water in the tank to ensure uniform temperature.

(4) Operate valves out of four valves provided on the panel in such a manner that the heat exchanger operates in parallel flow mode.

(5) Allow the hot water to flow through inner pipe side. Adjust the flow rate to the desired value using the rotameter. 
(6) Start the cold water supply on the outer pipe side. Adjust the flow rate to the desired value using rotameter.

(7) Observe the inlet and outlet temperature of both cold and hot water streams and record them after they achieve steady state condition.

(8) Record the flow rates of hot water and cold water with the help of rotameters.

(9) Repeat the procedure step number 6 to 9 for different flow rates of cold and hot water.

(10) Alter the opening of valves out of four valves provided on the panel in such a manner that now, the heat exchanger operates in parallel flow mode.

(11) Repeat the procedure step number 6 to 10 for counter flow arrangement of double pipe heat exchanger.

(12) Drain the water from both the tanks after completion of experiments.

\subsection{Calculation Steps for Double Pipe Heat}

\section{Exchanger}

The methodology adopted for calculation for experimentation and theoretical evaluation of overall heat transfer coefficient for double pipe heat exchanger for parallel and counter flow arrangements are described in subsection 2.2.1 and 2.2.2 respectively.

\subsubsection{Calculation Steps for Experimental}

\section{Evaluation of Overall Heat Transfer Coefficient}

(1) Flow Rate of Hot Water

$$
\mathrm{m}_{\mathrm{H}}=\mathrm{m}_{\mathrm{h}} \times \frac{\rho_{\mathrm{h}}}{60}
$$

(2) Flow Rate of Cold Water

$$
\mathrm{m}_{\mathrm{C}}=\mathrm{m}_{\mathrm{c}} \times \frac{\rho_{\mathrm{c}}}{60}
$$

(3) Heat Transferred by Hot to Cold Water

$$
\mathrm{Q}_{\mathrm{h}}=\mathrm{m}_{\mathrm{H}} \times \mathrm{C}_{\mathrm{p}, \mathrm{h}}\left(\mathrm{T}_{\mathrm{hi}}-\mathrm{T}_{\mathrm{ho}}\right)
$$

(4) Heat Transferred by Cold to Hot Water

$$
\mathrm{Q}_{\mathrm{c}}=\mathrm{m}_{\mathrm{C}} \times \mathrm{C}_{\mathrm{p}, \mathrm{c}}\left(\mathrm{T}_{\mathrm{co}}-\mathrm{T}_{\mathrm{ci}}\right)
$$

(5) Average Heat Transfer

$$
Q_{a v g}=\frac{Q_{h}+Q_{c}}{2}
$$

(6) Outer Surface Area of Inner Pipe

$$
\mathrm{A}_{\mathrm{os}, \mathrm{ip}}=\pi \times \mathrm{d}_{0, \mathrm{ip}} \times \mathrm{L}
$$

(7) Inner Surface Area of Inner Pipe

$$
\mathrm{A}_{\mathrm{is}, \mathrm{ip}}=\pi \times \mathrm{d}_{\mathrm{i}, \mathrm{ip}} \times \mathrm{L}
$$

(8) Logarithmic Mean Temp. Difference

For Parallel Flow Arrangement

$$
\operatorname{LMTD}=\frac{\left(\mathrm{T}_{\mathrm{hi}}-\mathrm{T}_{\mathrm{ci}}\right)-\left(\mathrm{T}_{\mathrm{h} 0}-\mathrm{T}_{\mathrm{co}}\right)}{\ln \left\{\frac{\left(\mathrm{T}_{\mathrm{hi}}-\mathrm{T}_{\mathrm{ci}}\right)}{\left(\mathrm{T}_{\mathrm{h} 0}-\mathrm{T}_{\mathrm{co}}\right)}\right\}}
$$

For Counter Flow Arrangement

$$
\operatorname{LMTD}=\frac{\left(\mathrm{T}_{\mathrm{hi}}-\mathrm{T}_{\mathrm{c} 0}\right)-\left(\mathrm{T}_{\mathrm{h} 0}-\mathrm{T}_{\mathrm{ci}}\right)}{\ln \left\{\frac{\left(\mathrm{T}_{\mathrm{hi}}-\mathrm{T}_{\mathrm{c} 0}\right)}{\left(\mathrm{T}_{\mathrm{h} 0}-\mathrm{T}_{\mathrm{ci}}\right)}\right\}}
$$

(9) Practical Overall Heat Transfer Coefficient based on Outer Surface Area of Inner Pipe

$$
\mathrm{U}_{\mathrm{o} \text {,pract }}=\frac{\mathrm{Q}_{\mathrm{avg}}}{\mathrm{A}_{\mathrm{os}, \mathrm{p} p} \times \mathrm{LMTD}}
$$

(10) Practical Overall Heat Transfer Coefficient based on Inner Surface Area of Inner Pipe

$$
\mathrm{U}_{\mathrm{i} \text {,pract }}=\frac{\mathrm{Q}_{\mathrm{avg}}}{\mathrm{A}_{\mathrm{is,ip}} \times \mathrm{LMTD}}
$$

\subsubsection{Calculation Steps for Theoretical Evaluation} of Overall Heat Transfer Coefficient

(1) Average Temperature of Cold Water

$$
\mathrm{T}_{\mathrm{avg}, \mathrm{c}}=\frac{\mathrm{T}_{\mathrm{ci}}+\mathrm{T}_{\mathrm{co}}}{2}
$$

(2) Average Temperature of Hot Water

$$
\mathrm{T}_{\mathrm{avg}, \mathrm{h}}=\frac{\mathrm{T}_{\mathrm{hi}}+\mathrm{T}_{\mathrm{ho}}}{2}
$$

(3) Obtain Following Parameters of Cold Water at Average Temperature of Cold Water

Density, $\rho_{c} ;$ Specific Heat, $C_{p, c}$;

Dynamic Viscosity, $\mu_{c} ;$ Prandtl No.,$P_{r, c}$ and Thermal Conductivity, $k_{c}$.

(4) Obtain Following Parameters of Hot Water at Average Temperature of Hot Water

Density, $\rho_{h} ;$ Specific Heat, $C_{p, h}$;

Dynamic Viscosity, $\mu_{h} ;$ Prandtl No.,$P_{r, h}$ and Thermal Conductivity, $k_{h}$. 
(5) Heat Capacity Flow Rate of Cold Water

$$
\mathrm{C}_{\mathrm{c}}=\mathrm{m}_{\mathrm{C}} \times \mathrm{C}_{\mathrm{p}, \mathrm{c}}
$$

(6) Heat Capacity Flow Rate of Hot Water

$$
\mathrm{C}_{\mathrm{h}}=\mathrm{m}_{\mathrm{H}} \times \mathrm{C}_{\mathrm{p}, \mathrm{h}}
$$

(7) Minimum Heat Capacity Flow Rate

$$
\mathrm{C}_{\text {min }}=\text { Minimum Value out of } \mathrm{C}_{\mathrm{c}} \text { and } \mathrm{C}_{\mathrm{h}}
$$

(8) Minimum Heat Capacity Flow Rate

$$
\mathrm{C}_{\max }=\text { Maximum Value out of } \mathrm{C}_{\mathrm{c}} \text { and } \mathrm{C}_{\mathrm{h}}
$$

(9) Maximum Possible Heat Transfer

$$
\mathrm{Q}_{\max }=\mathrm{C}_{\min }\left(\mathrm{T}_{\mathrm{hi}}-\mathrm{T}_{\mathrm{ci}}\right)
$$

(10) Effectiveness of the Heat Exchanger

$$
\epsilon=\frac{Q_{a v g}}{Q_{\max }}
$$

(11) Cross Sectional Area of Annulus through which Cold Water Flows

$$
A_{\text {annulus }}=\frac{\pi}{4} \times\left(d_{i, o p}^{2}-d_{o, i p}^{2}\right)
$$

(12) Velocity of Cold Water

$$
\mathrm{V}_{\mathrm{c}}=\frac{\mathrm{m}_{\mathrm{C}}}{\rho_{\mathrm{c}} \times \mathrm{A}_{\text {annulus }}}
$$

(13) Characteristics Diameter of Cold Water

$$
\mathrm{D}_{\mathrm{c}}=\left(\mathrm{d}_{\mathrm{i}, \mathrm{op}}-\mathrm{d}_{\mathrm{o}, \mathrm{ip}}\right)
$$

(14) Reynolds Number for Cold Water Flow

$$
\mathrm{R}_{\mathrm{e}, \mathrm{c}}=\frac{\rho_{\mathrm{c}} \times \mathrm{V}_{\mathrm{c}} \times \mathrm{D}_{\mathrm{c}}}{\mu_{\mathrm{c}}}
$$

(15) Nusselt Number for Cold Water Flow

$$
\mathrm{N}_{\mathrm{u}, \mathrm{c}}=0.023 \times\left(\mathrm{R}_{\mathrm{e}, \mathrm{c}}\right)^{0.8} \times\left(\mathrm{P}_{\mathrm{r}, \mathrm{c}}\right)^{0.4}
$$

(16) Heat Transfer Coefficient for Cold Water (Outside Heat Transfer Coefficient)

$$
\mathrm{h}_{\mathrm{c}}=\frac{\mathrm{N}_{\mathrm{u}, \mathrm{c}} \times \mathrm{k}_{\mathrm{c}}}{\mathrm{D}_{\mathrm{c}}}
$$

(17) Cross Sectional Area of Inner Pipe through which Hot Water Flows

$$
A_{c s, i p}=\frac{\pi}{4} \times\left(d_{i, i p}\right)^{2}
$$

(18) Velocity of Hot Water

$$
\mathrm{V}_{\mathrm{h}}=\frac{\mathrm{m}_{\mathrm{H}}}{\rho_{\mathrm{h}} \times \mathrm{A}_{\mathrm{cs}, \mathrm{ip}}}
$$

(19) Characteristics Diameter of Hot Water

$$
\mathrm{D}_{\mathrm{h}}=\mathrm{d}_{\mathrm{i}, \mathrm{ip}}
$$

(20) Reynolds Number for Hot Water Flow

$$
\mathrm{R}_{\mathrm{e}, \mathrm{h}}=\frac{\rho_{\mathrm{h}} \times \mathrm{V}_{\mathrm{h}} \times \mathrm{D}_{\mathrm{h}}}{\mu_{\mathrm{h}}}
$$

(21) Nusselt Number for Hot Water Flow

$$
\mathrm{N}_{\mathrm{u}, \mathrm{h}=} 0.023 \times\left(\mathrm{R}_{\mathrm{e}, \mathrm{c}}\right)^{0.8} \times\left(\mathrm{P}_{\mathrm{r}, \mathrm{c}}\right)^{0.3}
$$

(22) Heat Transfer Coefficient for Hot Water (Inside Heat Transfer Coefficient)

$$
\mathrm{h}_{\mathrm{h}}=\frac{\mathrm{N}_{\mathrm{u}, \mathrm{h}} \times \mathrm{k}_{\mathrm{h}}}{\mathrm{D}_{\mathrm{h}}}
$$

(23) Inner Overall Heat Transfer Coefficient

$$
=\frac{\mathrm{U}_{\mathrm{i}, \text { theo }}}{\left\{\frac{1}{\mathrm{~h}_{\mathrm{h}}}\right\}+\left\{\frac{\mathrm{d}_{\mathrm{i}, \mathrm{ip}} / 2}{\mathrm{k}_{\mathrm{ip}}} \times \ln \left\{\frac{\mathrm{d}_{\mathrm{o}, \mathrm{ip}} / 2}{\left.\left.\mathrm{~d}_{\mathrm{i}, \mathrm{ip} / 2}\right\}\right\}+\left\{\frac{\mathrm{d}_{\mathrm{i}, \mathrm{ip}} / 2}{\mathrm{~d}_{\mathrm{o}, \mathrm{ip}} / 2} \times \frac{1}{\mathrm{~h}_{\mathrm{c}}}\right\}}\right.\right.}
$$

(24) Outer Overall Heat Transfer Coefficient

$$
=\frac{\mathrm{U}_{\mathrm{o}, \text { theo }}}{\left\{\frac{1}{\mathrm{~h}_{\mathrm{c}}}\right\}+\left\{\frac{\mathrm{d}_{\mathrm{o}, \mathrm{ip}} / 2}{\mathrm{k}_{\mathrm{ip}}} \times \ln \left\{\frac{\mathrm{d}_{\mathrm{o}, \mathrm{ip}} / 2}{\mathrm{~d}_{\mathrm{i}, \mathrm{ip}} / 2}\right\}\right\}+\left\{\frac{\mathrm{d}_{\mathrm{o}, \mathrm{ip}} / 2}{\mathrm{~d}_{\mathrm{i}, \mathrm{ip}} / 2} \times \frac{1}{\mathrm{~h}_{\mathrm{h}}}\right\}}
$$

\section{PREPARATION AND CHARACTERIZATION OF NANOFLUID}

There are two techniques to prepare nanofluids viz. (1) the single-step method, in which nanoparticles are evaporated and directly dispersed into the base fluids and (2) the twostep method in which nanoparticles are made first and then disperses them into the base fluids. The basic requirement of preparation of nanofluid is to obtaine a well-mixed and uniformly dispersed nanofluid for successful reproduction of properties and interpretation of experimental data.

Two-step method has been employed to prepare nanofluid. $\mathrm{CuO}$ nanoparticles have been purchased from $\mathrm{M} / \mathrm{s}$. Jyotirmay Overseas, Rajkot. $\mathrm{CuO}$ nanoparticles of $40 \mathrm{~nm}$ size has $3610 \mathrm{~kg} / \mathrm{m}^{3}$ density. The proportion of $\mathrm{CuO}$ nanoparticles to be mixed with the base fluid i.e. water for different volume concentration is calculated using following 
equation. For different volume concentrations, the mass of nanoparticle to mix with the water is presented in Table 1. The $\mathrm{CuO}$ nanofluid prepared is shown in Figure 2.

$$
\begin{gathered}
\varnothing=\frac{\left\{\begin{array}{c}
\text { Volume of } \\
\text { Nanoparticle }
\end{array}\right\}}{\left\{\begin{array}{c}
\text { Volume of Nanoparticle } \\
+ \text { Volume of water }
\end{array}\right\}} \times 100 \\
\varnothing=\frac{\frac{W_{\text {nanoparticle }}}{\rho_{\text {nanoparticle }}}}{\frac{W_{\text {nanoparticle }}}{\rho_{\text {nanoparticle }}}+\frac{W_{\text {water }}}{\rho_{\text {water }}}} \times 100
\end{gathered}
$$

Table 1: Mass of $\mathrm{Al}_{2} \mathrm{O}_{3}$ Nano-dispersion to Mix with Water for Different Volume Concentration

\begin{tabular}{|l|l|l|}
\hline $\begin{array}{l}\text { Volume } \\
\text { Concentration, } \varphi \\
\text { in \% }\end{array}$ & $\begin{array}{l}\text { Quantity of } \\
\text { Base Fluid i.e. } \\
\text { Water in litres }\end{array}$ & $\begin{array}{l}\text { Mass of CuO } \\
\text { Nanoparticles to } \\
\text { be mixed with } \\
\text { water in grams }\end{array}$ \\
\hline 0.002 & 70 & 8.83 \\
\hline 0.003 & 70 & 13.25 \\
\hline 0.004 & 70 & 17.67 \\
\hline
\end{tabular}

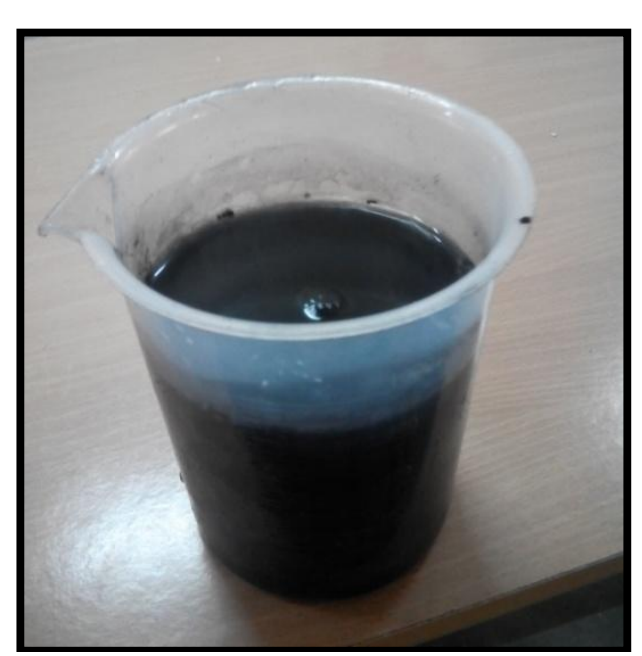

Fig. 2: CuO Nanofluid

The following equations are used to determine the density, specific heat, dynamic viscosity, thermal conductivity and prandtl number of nanofluid respectively.

$$
\begin{aligned}
& \rho_{\text {nanofluid }}=\left\{\varnothing \times \rho_{\text {nanoparticle }}\right\}+\left\{(1-\emptyset) \rho_{\text {water }}\right\} \\
& C_{p, \text { nanofluid }}= \frac{\left[\begin{array}{c}
\emptyset \times\left\{\rho_{\text {nanoparticle }} \times C_{p, \text { nanoparticle }}\right\} \\
+(1-\emptyset) \times\left\{\rho_{\text {water }} \times C_{p, \text { water }}\right\}
\end{array}\right]}{\rho_{\text {nanofluid }}} \\
& \mu_{\text {nanofluid }}=\left\{1+(7.3 \times \emptyset)+\left(123 \times \emptyset^{2}\right)\right\} \mu_{\text {water }} \\
& k_{\text {nanofluid }}= {\left[\begin{array}{c}
\left\{k_{\text {nanoparticle }}\right\}+\left\{2 \times k_{\text {water }}\right\} \\
+\left\{2 \times\left(k_{\text {nanoparticle }}-k_{\text {water }}\right) \times \emptyset\right\}
\end{array}\right] } \\
& {\left[\begin{array}{c}
\left\{k_{\text {nanoparticle }}\right\}+\left\{2 \times k_{\text {water }}\right\} \\
-\left\{\left(k_{\text {nanoparticle }}-k_{\text {water }}\right) \times \emptyset\right\}
\end{array}\right] }
\end{aligned}
$$

$$
P_{r, \text { nanofluid }}=\frac{\mu_{\text {nanofluid }} \times C_{p, \text { nanofluid }}}{k_{\text {nanofluid }}}
$$

\section{INTEGRATED RESEARCH METHODOLOGY}

The integrated methodology adopted to evaluate the effect of nanofluid on heat transfer characteristics of double pipe heat exchanger is presented below.

(1) Conduct the experiment using water as cold and hot fluid in double pipe heat exchanger as per the experimental procedure for double pipe heat exchanger.

(2) Calculate the practical value of overall heat transfer coefficient as per calculation steps for experimental evaluation of overall heat transfer coefficient for water as cold and hot fluid.

(3) Calculate the theoretical value of overall heat transfer coefficient as per calculation steps for theoretical evaluation of overall heat transfer coefficient for water as cold and hot fluid.

(4) Empty the water from the tanks of the double pipe heat exchanger.

(5) For $0.002 \%$ volume concentration, prepare the nanofluid by mixing 8.83 grams of $\mathrm{CuO}$ nanoparticles in water of 70 liters.

(6) Fill the nanofluid of $0.002 \%$ volume concentration into cold water tank. Now the nanofluid will work as cold fluid.

(7) Fill the water in hot water tank.

(8) Perform the experimentation and evaluate the overall heat transfer coefficient with nanofluid of $0.002 \%$ volume concentration as cold fluid and water as hot fluid as per the step number 1 to 4 of integrated research methodology.

(9) Perform the experimentation and evaluate overall heat transfer coefficient with nanofluid of $0.003 \%$ and $0.004 \%$ volume concentration as per the step number 1 to 4 of integrated research methodology.

(10) Compare the overall heat transfer coefficient of water with nanofluid for different volume concentration.

\section{RESULTS AND DISCUSSION}

Actual experimentation on double pipe heat exchanger has been carried out as per integrated research methodology. The results for parallel flow and counter flow arrangements are presented in Table 2 and Table 3 respectively. The overall heat transfer coefficients obtained practically and theoretically are plotted for parallel flow arrangement in Figure 3 and 4 respectively and the same are plotted for counter flow arrangement in Figure 5 and Figure 6 respectively.

The value of overall heat transfer coefficient increases in case of nanofluid having different volume concentrations as compared to water for parallel flow as well as counter flow arrangement for double pipe heat exchanger. The increase in practical value of outer and inner overall heat transfer coefficient is found to $54 \%$ and $56 \%$ in case of $\mathrm{CuO}$ nanofluid having volume concentration of $0.004 \%$ for parallel flow and the same is found to be $25 \%$ and $13 \%$ in 
case of $\mathrm{CuO}$ nanofluid having volume concentration of $0.004 \%$ for counter flow arrangement. The experimental value of overall heat transfer coefficients have been found in agreement with theoretical values.

Table 2: Result for Parallel Flow Arrangement

\begin{tabular}{|c|c|c|c|c|}
\hline \multirow{3}{*}{ 苞离 } & \multicolumn{4}{|c|}{$\begin{array}{l}\text { Average Overall Heat Transfer } \\
\text { Coefficient, } \mathrm{kW} / \mathrm{m}^{2 \mathrm{O}} \mathrm{C}\end{array}$} \\
\hline & \multicolumn{2}{|c|}{ Practical } & \multicolumn{2}{|c|}{ Theoretical } \\
\hline & Uo & $\mathrm{Ui}$ & Uo & $\mathrm{Ui}$ \\
\hline $\begin{array}{l}\text { Water to } \\
\text { Water }\end{array}$ & 0.27 & 0.32 & 0.31 & 0.38 \\
\hline $\begin{array}{l}\text { Nanofluid } \\
\text { of } \varphi=0.002 \\
\text { to Water }\end{array}$ & 0.41 & 0.49 & 0.42 & 0.50 \\
\hline $\begin{array}{l}\text { Nanofluid } \\
\text { of } \varphi=0.003 \\
\text { to Water }\end{array}$ & 0.41 & 0.50 & 0.43 & 0.50 \\
\hline $\begin{array}{l}\text { Nanofluid } \\
\text { of } \varphi=0.004 \\
\text { to Water }\end{array}$ & 0.42 & 0.50 & 0.47 & 0.57 \\
\hline
\end{tabular}

Table 3: Result for Counter Flow Arrangement

\begin{tabular}{|c|c|c|c|c|}
\hline \multirow{3}{*}{ 离离 } & \multicolumn{4}{|c|}{$\begin{array}{l}\text { Average Overall Heat Transfer } \\
\text { Coefficient, } \mathrm{kW} / \mathrm{m}^{20} \mathrm{C}\end{array}$} \\
\hline & \multicolumn{2}{|c|}{ Practical } & \multicolumn{2}{|c|}{ Theoretical } \\
\hline & Uo & $\mathrm{Ui}$ & Uo & $\mathrm{Ui}$ \\
\hline $\begin{array}{l}\text { Water to } \\
\text { Water }\end{array}$ & 0.36 & 0.43 & 0.36 & 0.43 \\
\hline $\begin{array}{l}\text { Nanofluid } \\
\text { of } \varphi=0.002 \\
\text { to Water }\end{array}$ & 0.39 & 0.46 & 0.41 & 0.49 \\
\hline $\begin{array}{l}\text { Nanofluid } \\
\text { of } \varphi=0.003 \\
\text { to Water }\end{array}$ & 0.40 & 0.48 & 0.45 & 0.51 \\
\hline $\begin{array}{l}\text { Nanofluid } \\
\text { of } \varphi=0.004 \\
\text { to Water }\end{array}$ & 0.45 & 0.48 & 0.46 & 0.53 \\
\hline
\end{tabular}

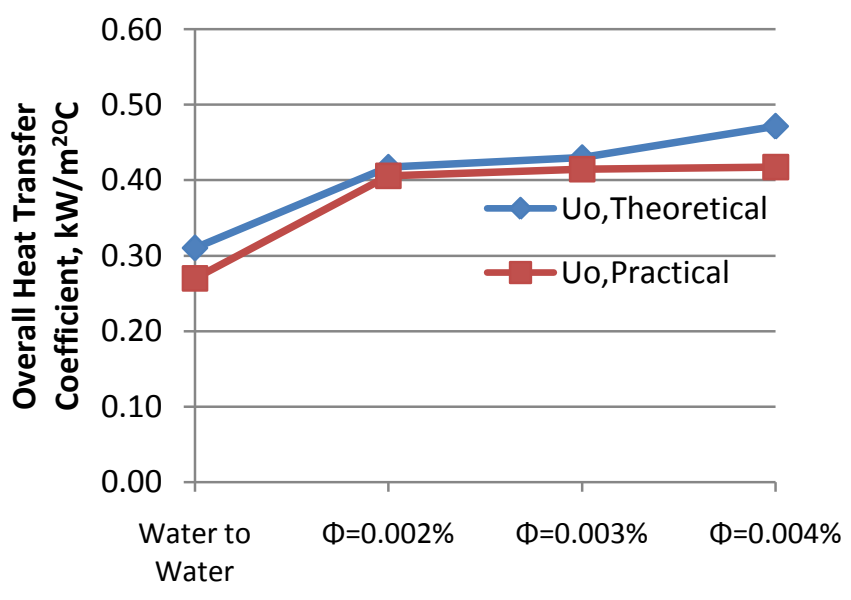

Heat Tranfer Media

Fig. 3: Theoretical and Practical Outer Overall Heat Transfer Coefficients for Parallel Flow Arrangement

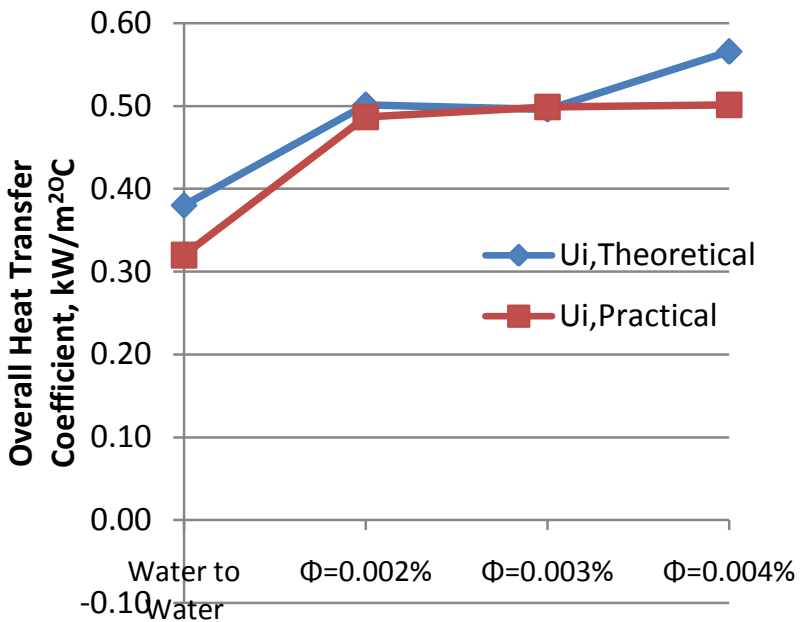

Heat Transfer Media

Fig. 4: Theoretical and Practical Inner Overall Heat Transfer Coefficients for Parallel Flow Arrangement

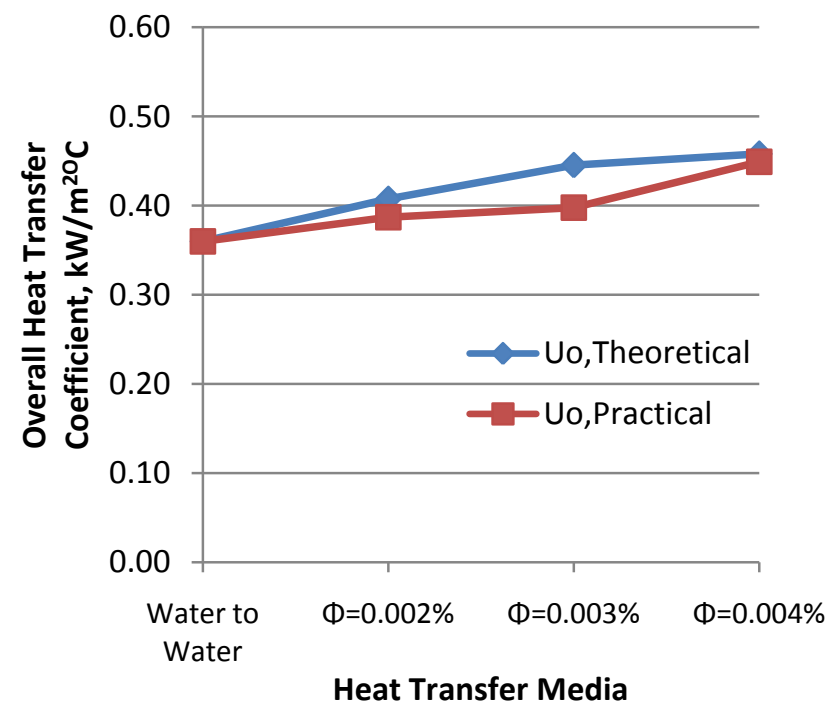

Fig. 5: Theoretical and Practical Outer Overall Heat Transfer Coefficients for Counter Flow Arrangement

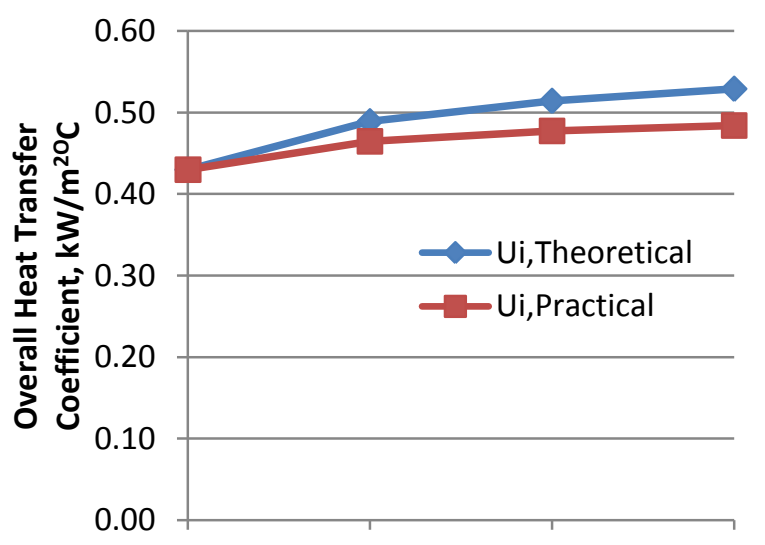

Water to Water $\Phi=0.002 \% \quad \Phi=0.003 \% \quad \Phi=0.004 \%$ Heat Transfer Media

Fig. 6: Theoretical and Practical Inner Overall Heat Transfer Coefficients for Counter Flow Arrangement 


\section{CONCLUSION}

An experimental investigation is carried out to determine the effect of various concentration of $\mathrm{CuO}$ nanoparticle mixed in water as base fluid on heat transfer characteristics of double pipe heat exchanger for parallel and counter flow arrangement. The volume concentrations of $\mathrm{CuO}$ nanofluid prepared are $0.002 \%, 0.003 \%$ and $0.004 \%$. The conclusion derived for the study is that overall heat transfer coefficient increase with increase in volume concentration of $\mathrm{CuO}$ nanoparticle as compared to water.

\section{ACKNOWLEDGEMENTS}

The author is extremely thankful to the staff members of Mechanical Engineering Department, A. D. Patel Institute of Technology, New Vallabh Vidyanagar for providing the useful resources and the management of the college and Charutar Vidya Mandal for providing financial support to carry out the experimentation work. The authors have also approached to GUJCOST for financial support. The authors are also thankful Jay R. Patel, Hardik H. Patel and Atul P. Parmar and other students of college for providing their untiring support and efforts wherever needed.

\section{REFERENCES}

[1] L. Léal, M. Miscevic, P. Lavieille, M. Amokrane, F. Pigache, F. Topin, B. Nogarède and L. Tadrist, An overview of heat transfer enhancement methods and new perspectives: Focus on active methods using electroactive materials, Internanational Journal of Heat and Mass Transfer, 61, 2013, pp. 505-524.

[2] N. K. Chavda, Jay R. Patel, Hardik H. Patel and Atul P. Parmar, Effect of Nanofluid on Heat Transfer Characteristics of Double Pipe Heat Exchanger: Part : I : Effect of Aluminum Oxide Nanofluid, International Journal of Research in Engineering and Technology (IJRET), Vol. 3, Issue 12, December 2014, pp. 42-52.

[3] Azher M. Abed, M. A. Alghoul, K. Sopian, H. A. Mohammed, Hasan sh. Majdi and Ali Najah AlShamani, Design characteristics of corrugated trapezoidal plate heat exchangers using nanofluids, Chemical Engineering and Processing: Process Intensification, Volume 87, January 2015, Pages 88103.

[4] V. Nikkhah, M. M. Sarafraz, F. Hormozi and S. M. Peyghambarzadeh, Particulate fouling of $\mathrm{CuO}-$ water nanofluid at isothermal diffusive condition inside the conventional heat exchanger-experimental and modeling, Experimental Thermal and Fluid Science, Volume 60, January 2015, Pages 83-95.

[5] S. M. Peyghambarzadeh, S. H. Hashemabadi, A. R. Chabi and M. Salimi, Performance of water based $\mathrm{CuO}$ and $\mathrm{Al} 2 \mathrm{O} 3$ nanofluids in a $\mathrm{Cu}-\mathrm{Be}$ alloy heat sink with rectangular microchannels, Energy Conversion and Management, Volume 86, October 2014, Pages 28-38.

[6] Fatou Toutie Ndoye, Patrick Schalbart, Denis Leducq and Graciela Alvarez, Numerical study of energy performance of nanofluids used in secondary loops of refrigeration systems, International Journal of Refrigeration, In Press, Corrected Proof, Available online 22 October 2014.

[7] M. A. Khairul, A. Hossain, R. Saidur, M. A. Alim, Prediction of heat transfer performance of $\mathrm{CuO} /$ water nanofluids flow in spirally corrugated helically coiled heat exchanger using fuzzy logic technique, Computers \& Fluids, Volume 100, 1 September 2014, Pages 123-129.

[8] M. A. Khairul, M. A. Alim, I. M. Mahbubul, R. Saidur, A. Hepbasli and A. Hossain, Heat transfer performance and exergy analyses of a corrugated plate heat exchanger using metal oxide nanofluids, International Communications in Heat and Mass Transfer, Volume 50, January 2014, Pages 8-14.

[9] M. A. Khairul, R. Saidur, M. M. Rahman, M. A. Alim, A. Hossain and Z. Abdin, Heat transfer and thermodynamic analyses of a helically coiled heat exchanger using different types of nanofluids, International Journal of Heat and Mass Transfer, Volume 67, December 2013, Pages 398-403.

[10] K. Narrein and H. A. Mohammed, Influence of nanofluids and rotation on helically coiled tube heat exchanger performance, Thermochimica Acta, Volume 564, 20 July 2013, Pages 13-23.

[11] H. A. Mohammed, Husam A. Hasan and M. A. Wahid, Heat transfer enhancement of nanofluids in a double pipe heat exchanger with louvered strip inserts, International Communications in Heat and Mass Transfer, Volume 40, January 2013, Pages 3646.

[12] H. A. Mohammed and K. Narrein, Thermal and hydraulic characteristics of nanofluid flow in a helically coiled tube heat exchangerInternational Communications in Heat and Mass Transfer, Volume 39, Issue 9, November 2012, Pages 1375-1383.

[13] N. Kannadasan, K. Ramanathan and S. Suresh, Comparison of heat transfer and pressure drop in horizontal and vertical helically coiled heat exchanger with $\mathrm{CuO} /$ water based nano fluids, Experimental Thermal and Fluid Science, Volume 42, October 2012, Pages 64-70.

[14] Amin Kazemi-Beydokhti and Saeed Zeinali Heris, Thermal optimization of combined heat and power (CHP) systems using nanofluids, Energy, Volume 44, Issue 1, August 2012, Pages 241-247.

[15] Gabriela Huminic and Angel Huminic, Heat transfer characteristics in double tube helical heat exchangers using nanofluids, International Journal of Heat and Mass Transfer, Volume 54, Issues 19-20, September 2011, Pages 4280-4287.

[16] H. A. Mohammed, G. Bhaskaran, N. H. Shuaib, R. Saidur, Numerical study of heat transfer enhancement of counter nanofluids flow in rectangular microchannel heat exchanger, Superlattices and Microstructures, Volume 50, Issue 3, September 2011, Pages 215-233. 
[17] Amirhossein Zamzamian, Shahin Nasseri Oskouie, Ahmad Doosthoseini, Aliakbar Joneidi, Mohammad Pazouki, Experimental investigation of forced convective heat transfer coefficient in nanofluids of $\mathrm{A} 12 \mathrm{O} 3 / \mathrm{EG}$ and $\mathrm{CuO} / \mathrm{EG}$ in a double pipe and plate heat exchangers under turbulent flow, Experimental Thermal and Fluid Science, Volume 35, Issue 3, April 2011, Pages 495-502.

[18] M. N. Pantzali, A. G. Kanaris, K. D. Antoniadis, A. A. Mouza, S. V. Paras, Effect of nanofluids on the performance of a miniature plate heat exchanger with modulated surface, International Journal of Heat and Fluid Flow, Volume 30, Issue 4, August 2009, Pages 691-699.

[19] M. N. Pantzali, A. A. Mouza and S. V. Paras, Investigating the efficacy of nanofluids as coolants in plate heat exchangers (PHE), Chemical Engineering Science, Volume 64, Issue 14, 15 July 2009, Pages 3290-3300.

\section{BIOGRAPHY}

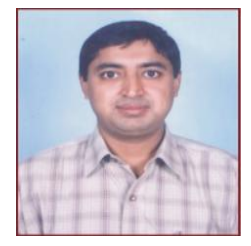

Dr. N. K. Chavda has completed M. E. (Mech) from SVNIT, Surat and Ph. D. from The M. S. University of Baroda. He has 19 years of teaching experience and published many papers in International Journals/Conference. He has been awarded with "Best Polytechnic Teacher" by ISTE, New Delhi and "The Dronacharya Award", for the admirable contribution in teaching-learning and overall development of students adjudged by ADIT and CVM. 